\title{
A lost chance for what? COVID-19 and its repercussions on global public opinion of China's development model and international leadership
}

\author{
Thomas Ameyaw-Brobbey \\ Faculty of Law and Public Administration, Yibin University, \\ China P.R. \\ qophi77@yahoo.com/tamebrobb77@,gmail.com \\ ORCID 0000-0002-8914-2915
}
Abstract. This paper gauges COVID-19's effect on global public perception of China and the likely implications for China's development model and international influence. How does COVID-19 affect China's exercise of soft power and the international community's appraisal of it? Using global perception data from the Pew Research Centre, the paper argues that COVID-19 is likely to have dire consequences on China's soft power and international influence based on the soft power theory. Specifically, China lost a chance to present the attractiveness of its development model - Beijing Consensus - and establish credibility for global leadership due to the universal perception of the relationship between the pandemic and China despite the country's international efforts. The paper concludes that this will validate people's opinions about China and accelerate an already existing trend - unfavourable image. The paper serves as a new scientific contribution to the literature on soft power and foreign policy.

Keywords: COVID-19 Pandemic, soft power, image-building, global public opinion, China's Model - Beijing Consensus, international leadership, conspiracy theories.

JEL Classification: F50, F59, I10, N40

\section{INTRODUCTION}

China notified the world of a virus outbreak in late December 2019. By the time the country was able to bring the virus under control, it was peaking across the globe. As the world is still dealing with COVID19, it is essential to examine how the world's people view China and the implications for China's development model and international image and influence. This is the overarching purpose of the present paper. How does COVID-19 affect China's exercise of soft power and the international community's appraisal of it? The paper answers this question using opinion polls from the Pew Research Centre (20172020) and the Afrobarometer survey (2016) (Lekorwe et al., 2016). It utilises narrative analysis and phenomenological method. The central argument is that COVID-19 is likely to have dire consequences on 
China's soft power and international influence. Specifically, China lost a chance to present the attractiveness of its development model - Beijing Consensus - and establish credibility for global leadership due to the universal perception of the relationship between the pandemic and China despite the country's strenuous international efforts. Thus, this will validate people's opinions about China and accelerate an already existing trend - unfavourable image. The theoretical argument is based on the soft power literature.

This study adds a new contribution to the soft power literature through its application to China's international order-building efforts. It shows that others' admiration and appreciation of your ideas and values and their readiness to accept them are vital considerations for global leadership. It also makes a valuable addition to the emerging body of literature that relates COVID-19 to international relations and public diplomacy, and has policy relevance. Media sources might make the paper seem journalistic, but they have proven to be essential supplements since COVID-19 is a new phenomenon with limited academic research.

China has done more with regards to the COVID-19 pandemic than any other country in the international arena. While the US ignored the threat of the pandemic, China recognised the need for a coordinated global response spearheaded by solid leadership (see Campbell \& Doshi, 2020; Chen, li, \& Lin, 2020; Crawford, Martin, \& Bloomberg, 2020). However, such a role is unlikely to increase China's credibility in the eyes of the worldwide public. Achieving international support for leadership - legitimacy - is imperative as military and economic superiority alone are inadequate. Joseph Nye explained that one way to achieve this support is through soft power. That is, getting other countries and their peoples to do your bidding through attraction rather than coercion - and "the ability to share information - and to be believed - [is] an important source of attraction and power" (Nye Jr., 2004, p.31).

Goldsmith and Horiuchi (2009) argued that the US' leadership credibility in the eyes of foreign publics is critical in shaping perceptions and attitudes towards its external engagements. Soft power manifests in the "views held by country's B's public about country A's foreign policy," and that, "public opinion about US foreign policy in foreign countries does affect their policies toward the US, but this effect is conditional on the salience of an issue for mass publics" (Goldsmith \& Horiuchi, 2012, pp.556-57). Cho and Jeong (2008, p.455) argued that China's soft power resource - Beijing Consensus - plays a vital role in its increasing influence in Asia. Thus, this work will examine how foreign public views of China's actions - shaped by its political culture and values - on COVID-19 affect this soft power resource and international standing.

There is an emerging body of literature on COVID-19 and how it is likely to shape international relations. Campbell and Doshi (2020) argue that the implications of COVID-19 could serve as a critical juncture to change the US global position in the long run because it is failing the legitimacy test set by the pandemic. Peckham (2020) believes that although past epidemics have previously exposed China's weakness, COVID-19 signifies Beijing's strength because its response and management have affirmed a strong central authority. China's ability to rapidly beat the pandemic at home enabled it to extend a helping hand to others. Thus, Smith and Fallon (2020) believe that China can use this opportunity to build its international image by forging meaningful friendships through its COVID-19 aid. However, others have a different opinion. Haass (2020) argues that instead of the pandemic reshaping world order, it is likely to accelerate it by building a more robust international order to foster greater cooperation and renewed commitment to address critical global problems. Kavalski (2021) explains that the pandemic does more harm than good to China's international image in Central and Eastern Europe (CEE) because it validates CEE's negative opinions of China and its global identity. Thus, Pei (2020) predicts that COVID-19 will trigger internal security challenges and upheaval that is "likely to expose the brittleness and insecurity that lie beneath the surface of Xi's, and Beijing's, assertions of solidity and strength."

The present work gauges COVID-19's effect on the global public perception of China and its likely implication on China's model and international influence. To do this, first, it explains the soft power theory, 
the dataset, and the research method. Second, it briefly describes the global public narrative or perception about the virus outbreak. Then, it assesses China's developmental strategy - Beijing Consensus - as a soft power resource. The following two sections examine how the Chinese government attempts to control the international narratives to garner support for its model through aid. It drives the argument that COVID-19 is likely to have dire consequences on China's soft power and international influence because of possible attachment loss between China and the global public. Thus, it has cost China a chance to present its developmental model's attractiveness to the world's people. The final section offers concluding remarks.

\section{THE SOFT POWER THEORY AND CHINA}

Power is mainly seen as the ability to control others or get others to do what in a normal condition they would not do. Military, technology, economic strength, and even productive population are essential power sources in the international system. Countries exercise such power through coercion, inducement, payments and threats. Another form of power takes explanatory currency from variables that are difficult to measure, such as the attraction of one's culture and values which Joseph Nye referred to as soft power (Nye Jr., 1990, pp.166-67). He wrote that "soft power is the ability to affect others to obtain the outcomes one wants through attraction rather than coercion or payment" (Nye Jr., 2008, p.94). A country gets others and their citizens to admire its values and culture, change their behaviour and value preferences, and willingly emulate its examples. Soft power shapes the preferences of other states using co-option, persuasions, enticements and attractions through intangible means rather than coercion.

A country's soft power mainly rests on three resources: its culture, political values, and foreign policies seen as legitimate with a moral authority (Nye Jr., 2004, p. 11). According to Nye Jr. (2004, p.167), "if a state can make its power seen legitimate in the eyes of others, it will encounter less resistance to its wishes. If its culture and ideology are attractive, others will more willingly follow." The basic understanding is that a country can achieve its strategic interests without resorting to coercion or inducement, but instead through attraction or projecting a positive image to win hearts and minds. Since soft power is embedded in intangible variable sources, one way to measure its influence is through public opinion polls. However, it is difficult to predict or ascertain when soft power has affected the desired outcomes. Thus, "whether the attraction, in turn, produces designed policy outcomes has to be judged in each particular case" (Nye Jr., 2008, p.95). With no threshold, judging also depends on the individual making the judgment and must be within a specific context.

Although China has historically exercised soft power in its foreign policy and international relations conduct (Gill \& Huang, 2006), the phrase first appeared in Chinese academic journals in the late 1990s (Wang \& Lu, 2008). It gained considerable attention in China's official community in the early 2000s (Zhou \& Luk, 2016). Existing literature uses the theory to discuss China in varying degrees and perspectives. For example, Gill and Huang (2006) contend that Chinese soft power lies in cultural traditions. Therefore, domestic political values and foreign policy objectives present sources through which China draws soft power. Nevertheless, China is constrained in developing an ideal mix of soft power resources that can enhance its international image because it is weak in marketing its cultural products (Gill \& Huang, 2006). $\mathrm{Li}$ and Worm (2011) corroborate, arguing that China has a genuine desire to rise peacefully. Thus, the means to achieve this rise are Chinese moral and cultural attractions, economic development model, political values, and foreign policies that build international institutions and image embedded within the framework of soft power. Although China may reform the current global system to correct the perceived imbalances, it will do so within its soft power mechanisms without resorting to military force (Li \& Worm, 2011).

From Jiang Zemin to Xi Jinping, China places soft power high on its foreign policy agenda and makes concerted efforts to project it. One platform through which China promotes soft power in aid of the 
peaceful rise is establishing Confucius Institutes as part of cultural and public diplomacy. However, Zhou and Luk (2016) believe that the Confucius Institutes cannot enhance China's soft power and image abroad because their operationalization does not fit into the soft power definition. Countries worldwide see them as propaganda tools and unattractive, threatening academic freedom and local communities. Thus, instead of easing, Confucius Institutes present and reinforce a new version of the China threat mantra (Zhou \& Luk, 2016). Economic initiatives drive China's international engagement and image-building efforts worldwide. Thus, Liang (2012) notes that China intertwines economic power and soft power, making it difficult to distinguish between them. Although China advances soft power with economic incentives, there are limits to its utility because economic power alone is insufficient for China to project its image abroad.

\section{DATA DESCRIPTION AND METHOD}

The analysis I build in this paper depended on public perception data from the Pew Research Centre surveys published between 2017 and 2020 and supported with an Afrobarometer round six surveys that measured Africans reception to foreign influence (Lekorwe et al., 2016). I used data from the Pew Research Centre because it is globally recognised and accepted, while the Afrobarometer was used because of its credibility on African perception polls. Although the round six data is old, I used it because it is the institution's latest dataset that specifically measured Africans' perceptions of China - questionnaire numbers 80A-81E. The latest (Round 7) did not undertake this task. The Pew Research Centre December 5, 2019 survey recorded a split global public opinion median of $40 \%$ (favourable) and $41 \%$ (unfavourable) across 34 countries of China shown in figure 1 (Silver, Devlin \& Huang, 2019). Russia held the highest favourability (71\%), followed by Nigeria $(70 \%)$, and then Lebanon (68\%) and Israel (66\%). China and Russia have in recent history maintained an excellent relationship encompassing economic and political dimensions. Apart from various trade deals, including energy, both countries have demonstrated shared political interests on some issues, including Syria in 2011, Libya (2011), Sudan (2012), Iraq (2002), and Iran (2006) as permanent members of the United Nations Security Council. The root of this goodwill could stem from their communist tradition as well as the American factor.

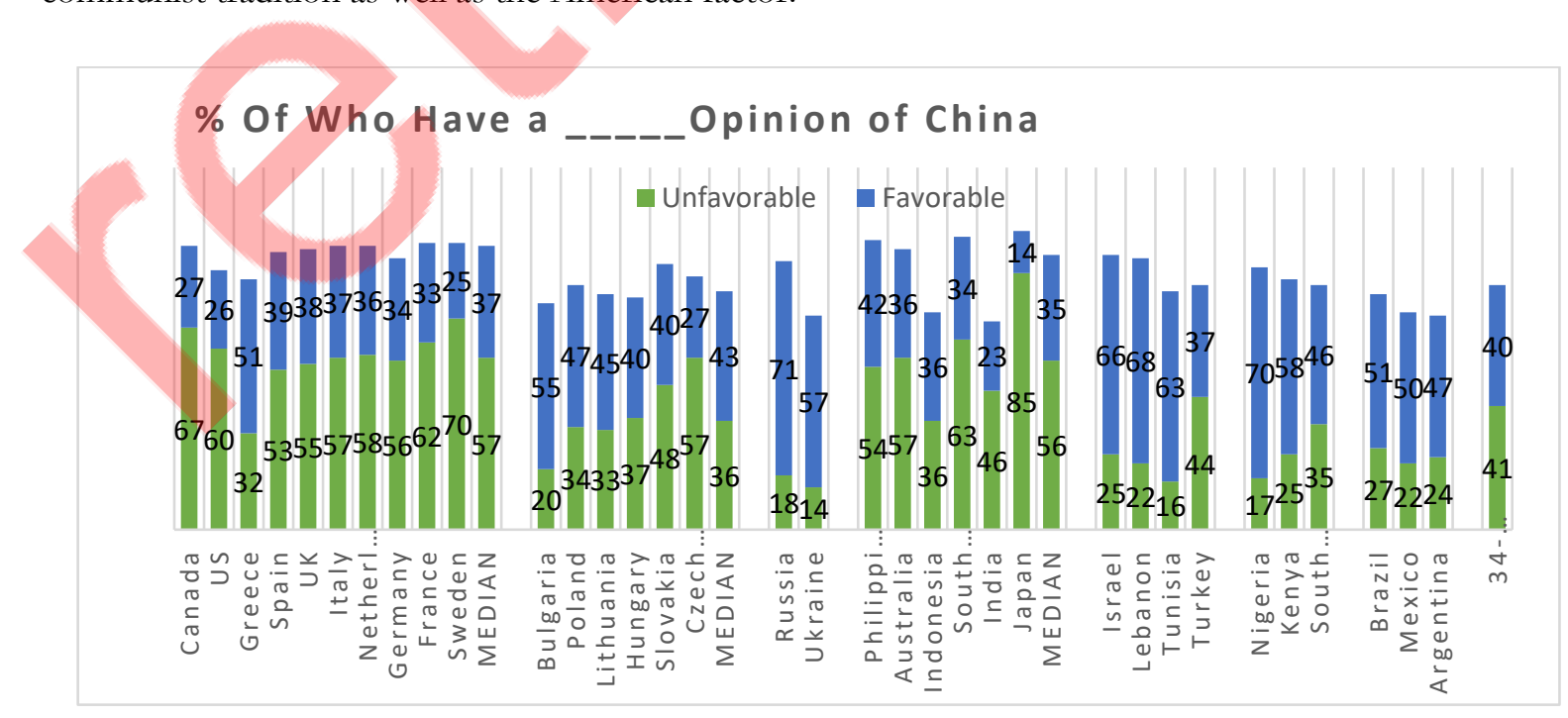

Figure 1. Global Opinions of China (2019)

Source: Silver, Devlin \& Huang (2019, December 5), Pew Research Centre.

https://www.pewresearch.org/fact-tank/2019/12/05/people-around-the-globe-are-divided-in-theiropinions-of-china/ 
China's favourability in Africa might stem from investments in infrastructure, Chinese products and technology, and economic payments, including loans and debt reliefs. Unsurprisingly, Japan held the highest unfavourable view (85\%). Although there is high economic interdependence, relationship and views of each other are guided by historical and territorial conflicts such as Japan's imperial occupation of China and China's principle that Japan must atone for historical sins and issues on Senkaku/Diaoyu Islands. Generally, China's Asian neighbours held unfavourable views because they see China's growing economic and military strength as threatening (Silver, 2017). Europe's view on China was generally unfavourable, although those in Western and Northern Europe were unfavourable than those in Central and Eastern Europe. Figure 2 shows that all ten countries surveyed in 2018 had no confidence in the Chinese leader, with a median score of $62 \%$ (Devlin \& Huang, 2019). The generally unfavourable Europe's view of China could stem from economic, trade and Chinese manufactured goods, political authoritarianism, and human rights. A March 2020 Pew Research Centre updated data that measured global preference for either the US or China with 33 countries shows that more people worldwide have a favourable perception of the US (21) than China (seven) shown in figure 4. Comparing the various figures in this paper reveals that China's favourability comes from developing and Middle East countries and Russia.

Data on global perception of China's handling and role in the spread of the virus was not available at the time of manuscript preparation. Nevertheless, a survey conducted from June 16 to June 14 2020, shows that Americans' fault China for its role in COVID-19 spread. Unfavourable view increased to $73 \%$, and $78 \%$ indicated that the Chinese government's initial handling of the outbreak is to be blamed for the global spread and that China should be held responsible for its role in the pandemic shown in figures 3 (Silver, Devlin, \& Huang, 2020). American public views do not represent a global view. However, the point I drive here is that the US' bottom-up soft power and strategic narratives play a significant role in shaping international perceptions through various media affiliates. Thus, its position on global issues and public views on COVID-19 could have significant psychological effects and influence global public opinion. Therefore, I state hypothesis one as:

H1: The outbreak of the COVID-19 pandemic from China is likely to validate the global public image of China and accelerate the negative perceptions.

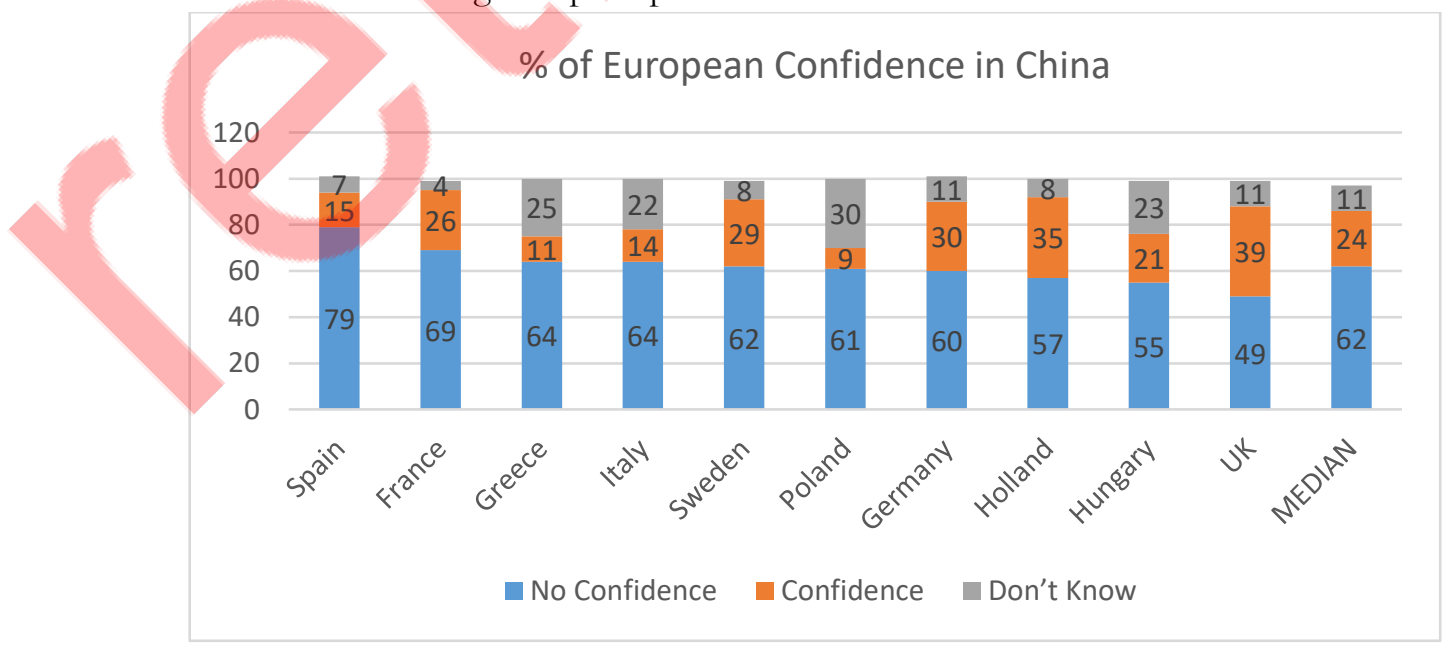

Figure 2. Europeans have no Confidence in China's Regime

Source: Devlin \& Huang (2019, March 22), Pew Research Centre. https://www.pewresearch.org/fact$\operatorname{tank} / 2019 / 03 / 22 /$ few-europeans-confident-in-xi-as-he-seeks-to-extend-chinese-economic-influence-inthe-region/ 


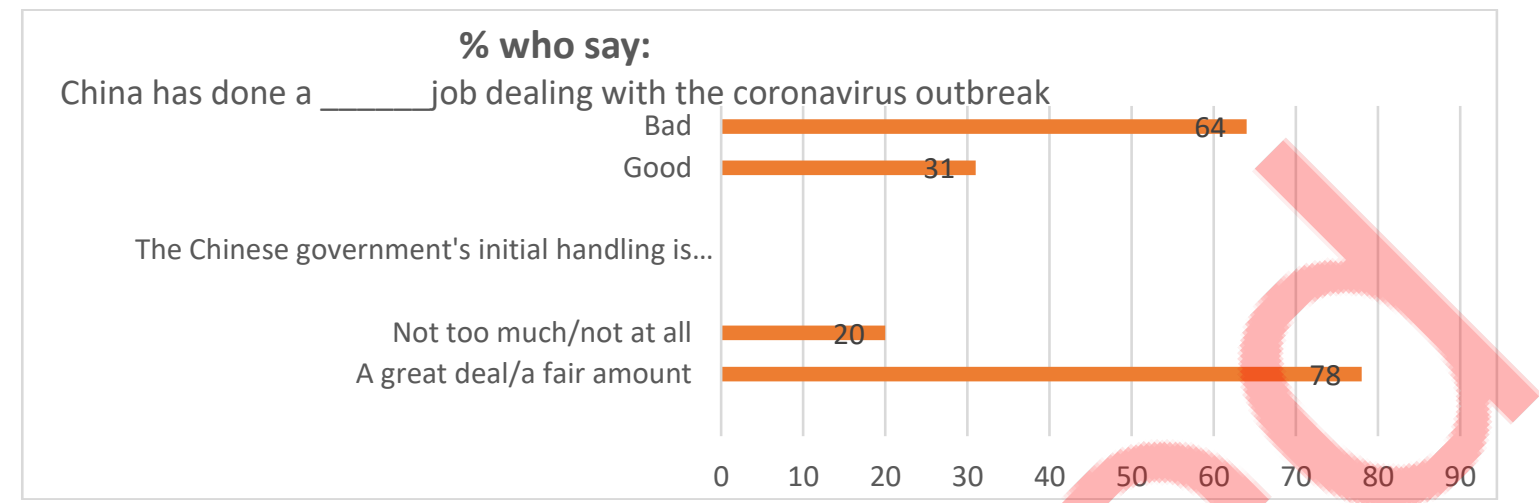

Figure 3. Americans Fault China for COVID-19 (July 2020)

Source: Silver, Devlin, and Huang (2020, July 30), Pew Research Centre.

https://www.pewresearch.org/global/2020/07/30/americans-fault-china-for-its-role-in-the-spread-ofcovid-19/ (accessed September 2, 2020)

These datasets were analysed with a qualitative research method that combined narrative analysis with a phenomenological approach. Lune and Berg (2017, p.12) wrote that "we adopt more qualitative methods when we need a deeper understanding of the exceptions and special cases, or when we want to understand the meanings and preferences that underlie those larger patterns." This paper aims to investigate and analyse how people's experiences of a specific event - COVID-19 - would likely affect China's international image. Thus, employing a narrative and phenomenological approach helped gain insights into the what, how, and why global publics think, feel, and would likely behave in a particular way towards China's model. The phenomenological study focuses on human behaviour, how individuals give meanings to social phenomena in their everyday lives to aid their interpretation of the world (Reeves, Albert, Kuper, \& Hodges, 2008, p.631). With narrative analysis, I situated COVID-19 theories with the dataset. The product of this process was analysed within the soft power theoretical framework to conclude from a global public perspective.

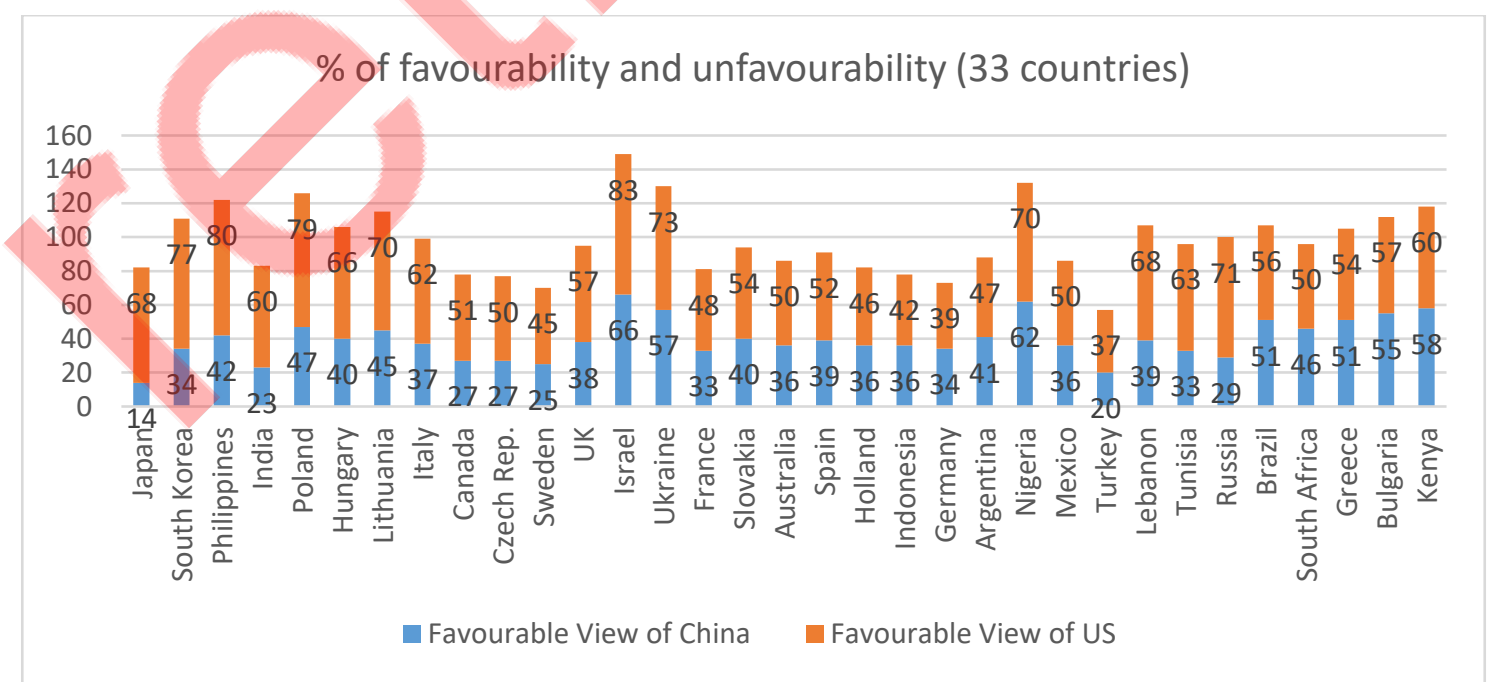

Figure 4. Global Public Preference for the US and China (January 2020)

Source: Silver, L. \& Devlin, K. (2020, January 10). Pew Research Centre.

https://www.pewresearch.org/fact-tank/2020/01/10/around-the-world-more-see-the-u-s-positivelythan-china-but-little-confidence-in-trump-or-xi/ (accessed August 16, 2020). 


\section{INTERNATIONAL PUBLIC THEORIES AND COVID-19 NARRATIVES}

The initial fear and inadequate information on the virus were fertile grounds for rumours and conspiracies and fanned by the distrust between the US and China. They centred on two issues: the virus is a biological weapon - and depending on who is making the conspiracy - it is made either by China or the US. The first conspiracy linked the COVID-19 virus with HIV in a preprint research paper. It claimed that the virus's protein sequence included short insertions with "uncanny similarity" to HIV-AIDS - making it likely to have a human involvement (Pradhan et al., 2020). Websites quickly picked on this. The Zero Hedge picked it and asserted that the COVID-19 virus was created by scientists in China as a weapon and again claimed that Chinese scientists had stolen the virus from a Canadian lab for a bioweapon program (Durden, 2020a; Durden, 2020b). A scientifically related theory from the South China University of Technology held that the virus might have originated from the Wuhan Center for Disease Control and Prevention, where a bat had once attacked a researcher (Lentzos, 2020). Although there is no proper evidence supporting such accidental leaks, such accidents are not uncommon in China due to general biosafety concerns (Zhiming, 2019). Events in China between February and March 2020 might have also given impetus to such a claim. The regime appointed a bioweapon expert to head the biosafety level-4 lab. President Xi announced the need to incorporate biosecurity and biosafety into the national security agenda (Huang, 2020). In another conspiracy, a purported 1981 thriller by Dean Koontz - "The Eyes of Darkness" - predicted a coronavirus outbreak in 2020 in a story of a Chinese military lab that creates a virus to potentially use as a biological weapon (Napoli, 2020). Another conspiracy from an unknown source tells a story of a biological agent project meant for Hong Kong protesters but spilt and spread in shootouts between China and the US during a handing over. It was connected to religion in Africa: the end time has come, and China is the anti-Christ using COVID-19 and 5G internet to unleash wickedness to end human existence (PASDO, 2020).

However, "while such rumors are not credible... they are difficult to dispel because military officials on both sides still view with suspicion each other's motives in building biosecurity programs" (Huang, 2020). The US and China mistrust each other with suspicion of continued manufacturing and possession of significant bioweapon capabilities. It is accentuated by considerable secrecy in Beijing's military development and President George W. Bush's rejection of protocol to the BWC in 2011. President Trump called it a "Chinese virus" and insisted that "everyone knows it came out of China." Chinese statesmen also claimed that US soldiers deliberately shed the virus during the 2019 World Military Games, saying "it might be the US Army who brought the epidemic to Wuhan" (Walden, 2020). An Iranian official supported the Chinese claim. The US politicians have also fanned the idea that even if China did not create the virus, it made the conditions for its rapid spread. Japan used germ warfare against China through its bio-warfare Unit 731, prompting China to set up its Academy of Military Medical Sciences (AMMS) in 1951 to conduct biodefense research and build defensive biological warfare facilities (Martin, 2002). However, the effect of bioweapons during warfare is not instantaneous, with an added possibility of infecting one own forces. Therefore, it is difficult to argue that the US and China manufactured the coronavirus to potentially use for warfare. Virologists have dismissed these claims, leaving us with the only findings that the virus is a problem of zoonotic (McDonald, 2020). However, the global public holds on to such claims because the influence the US wields over global media and its ability to reach a larger audience makes the tale that the Chinese government was behind the virus outbreak gains more traction among the worldwide public. Moreover, the theories target ordinary people through social media. Thus, although they are dismissed, such research does not transcend beyond elites and academia. 


\section{THE CHINA MODEL - BEIJING CONSENSUS - AS A SOFT POWER RESOURCE}

American politicians have consistently advanced the argument that there is no viable alternative to the liberal order. However, China's rapid economic growth has made it possible to rewrite this narrative (Zhao, 2010, p.420). Development took an experimental approach embedded with at least three spheres - global integration and market economy-oriented rules, top-down state-led strategies and bottom-up interpersonal networking. Beijing refers to it as "Socialism with Chinese Characteristics" (Xi, 2017, pp.3-70). In the model, China actively pursued foreign direct investment, which made foreign companies an essential part of economic growth, relied on the stock market for capital mobilisation and embarked on market liberalisation that strengthened firms (Cho \& Jeong, 2008, p.464). The government owns and controls important companies that dominate their industries, such as energy companies like Sinopec and Petro China. Government appoints senior directors of the largest and critical companies who are expected to become members of the Communist Party. Ownership and control allow the state to direct companies to high priority and strategic projects, give expert advice, issue early signals, and manage prices of exports and imports through the Bank of China without directly appearing in public. These measures allow the government to influence companies to help achieve foreign objectives. For example, when China wants to increase influence outside, say, an Africa country, it directs major Chinese companies such as construction companies to increase investment in those places. To support companies operating in those places, it gives directives to banks to increase lending to such companies (Naughton, 2010; Kurlantzick, 2013).

Ramo (2004, pp.3-4) referred to the China model as "Beijing Consensus"1 and explained with three theorems: a development model based on innovation; that considers sustainability and equality as a priority and strives for self-determination in foreign policy. According to him, this model has given hope to developing countries who have mostly suffered under the Washington Consensus, which applies neoliberal economic principles without considering countries' specific needs and characteristics. The Beijing Consensus highlights the ingenuity and achievements of China's 1978 economic reforms. The American model has lost steam since the 2008 financial crisis. Whiles others crumbled, China came out of the crisis stronger and rose rapidly into prominence, lending to countries and organising institutions such as the BRICS. Thus, a faltering American will for leadership and a renege on global responsibility marks today's world (Zhao, 2010, pp.432-433). Not only has it not rallied the world to confront COVID-19, but its domestic failures also leave governments no source of inspiration to confront the problem domestically. Developing countries have seen the frustrations associated with American liberal capitalism and promise of China's model and are ready to replicate it (Zhao, 2010, p. 419). Apart from the inability of liberal capitalism to rescue developing countries, foreign publics might lose faith in the American values they have long cherished due to gun violence and police brutality. A case is George Floyd's death that popularised the Black Lives Matter movement.

Beijing has spotted a vacuum to fill. It could promote and make its development model attractive to other countries to learn and adopt. By doing so, they will likely align with China and share its values. Its development style is gaining influence around the globe, pitting it against the liberal capitalist type and offering an alternative to the Washington Consensus (Zhao, 2010). According to Ramo (2004), the China model contains some crucial implications for the developing world. Specifically, it shows capitalist policies can be combined with the remnants of socialism while maintaining a strong political system to achieve

\footnotetext{
1 Although scholars such as Cho and Jeong (2008), Naughton (2010), Kennedy (2010) have used it, the phrase is not a consensus among Chinese scholars and not officially promoted by China. They are careful in using it. However, it has not been declined, preferring to use the phrase 'China Model' (see Xiaoyang, 2020; Zhao, 2010). The use of it in this work is a matter of convenience, referring to the same explanation as the "China Model or Socialism with Chinese Characteristics."
} 
economic growth and development (Zhao, 2010). In effect, the Chinese development model is a practical soft power resource. For example, Africans generally have a favourable view of China (63\% favourability). The most important factors contributing to the favourable perceptions of China are its infrastructure or development and business investments, and the cost of Chinese products (Lekorwe et al., 2016, pp. 3-21). This is made possible by the Chinese development model. In this regard, Africans prefer the Chinese model of development. The US is still ahead of China, but the difference is very marginal, $30 \%$ and $24 \%$, respectively, as shown in figure 5 .

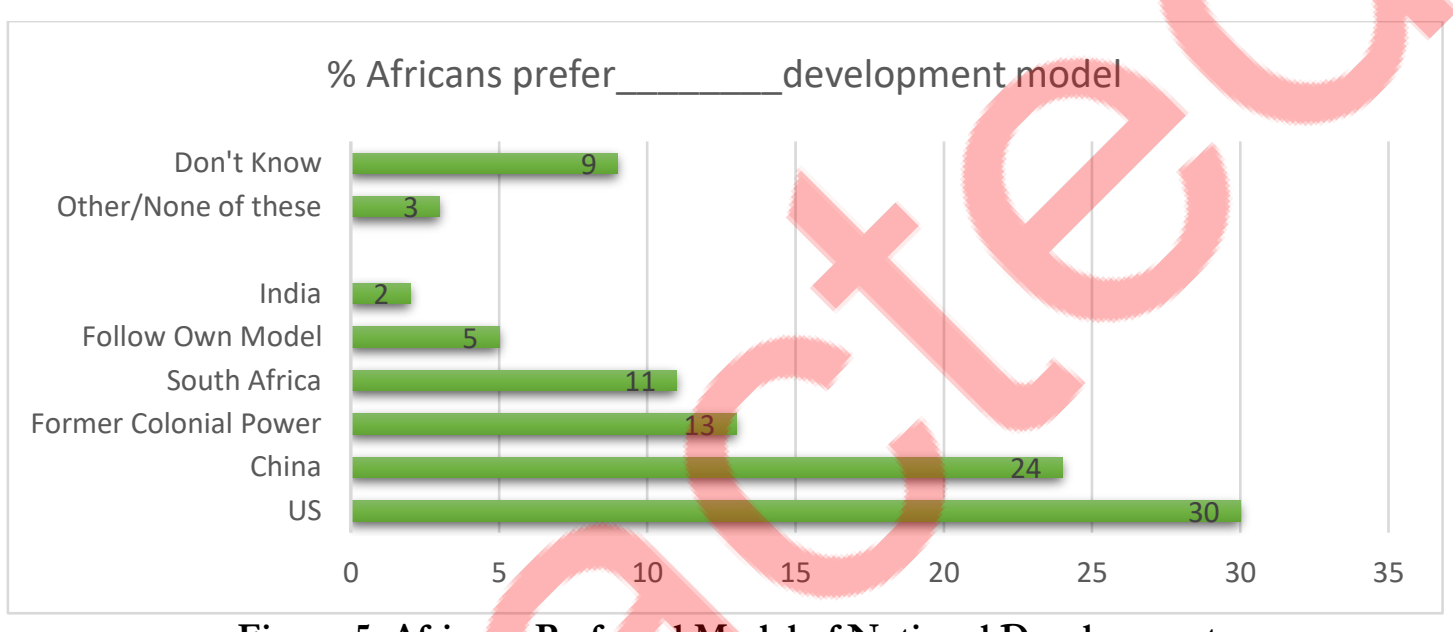

Figure 5. Africans Preferred Model of National Development

Source: Lekorwe et al. (2016, p.4), Afrobarometer Round 6.

https://afrobarometer.org/sites/default/files/publications/Dispatches/ab $\mathrm{r} 6$ dispatchno122 perception s_of china in africa1.pdf (August 12, 2020).

Naughton (2010) agrees with the distinctiveness of the Chinese development model. However, a 'consensus' should imply a universal understanding and acceptance. Thus, we can only talk about the model's consensus status if it is accepted by all and goes on to shape other's development. However, while it provides important lessons for the world, the disagreement of Chinese scholars and economists on many fundamental issues reduces its 'consensus' status. Its specific characteristics also make it difficult to be replicated by developing countries, defeating it as a model for the world. Thus, the model's characteristics are unique to China, whose characteristics are distinct from other countries (Naughton, 2010, pp. 454-456). From a similar perspective, Kennedy (2010) argues that the Beijing Consensus is a myth because it gives a misguided and inaccurate description of China's development experience. Despite these doubts, Zhao (2010) agrees with Ramo (2004) and shows that the China Model offers a distinctive economic and political development model in which a free market and a strong state control can co-exist to maintain economic growth and political stability. Therefore, other countries can replicate this model to replace their Washington modernization model because it offers strong appeals to leaders and their public.

The major difficulty is China must first convince the world's public - not only leaders - of the attractiveness of its model and credibility to lead. Thus, the regime has developed training programs and academic courses to train foreign officials and graduate students. For example, "each year, the national government of China provides 10,000 government scholarships to participating countries of the Belt and Road Initiative" and other developing countries to study various courses in China (Xi, 2017, p.558). China hopes to enhance its image and soft power resource by co-opting and embracing the future elites of developing countries as friends (Qi, 2010). Thus, I state hypothesis two here as: 
H2: The expansion of humanitarian aid - COVID-19 aid - is likely to help China present the attractiveness of its development model - Beijing Consensus - to the world's public.

\section{INFLUENCE, SOFT POWER AND CONTROL OF THE GLOBAL NARRATIVE}

\subsection{Seeking influence to control the international narratives}

Global public opinions accuse China's leadership of bungling the state's response to the COVID-19 outbreak and aiding its global spread. A short account of events is instructive. According to the WHO, the first confirmed case in China was on December 8. The Lancet puts the date at December 12019 , while another account traces it to November 17 2020, in Hubei Province, before medical practitioners could identify the virus (PTI, 2020a). On December 25, medical staff in Wuhan were reportedly affected by an unknown pneumonia type, suggestive of human-human transmission (Feng \& Cheng, 2020). Two doctors - Li Wenliang and Xie Lanka - independent from each other quietly warned colleagues and friends through a social media platform - WeChat - of possible SARS cases on December 30 2019. In what has become part of the charges against the Chinese regime for its irresponsibility, the doctors and six others were summoned and reprimanded by local police on January 1 2020, for disseminating rumours. Despite a contagious pneumonia outbreak report, Wuhan hosted a holiday banquet on January 18 2020, attended by 40000 people when about 136 cases had been confirmed. On January 23 2020, the government announced a Wuhan seal off - a city of 11 million people - from the rest of the country when about 619 cases had been confirmed. Although this measure intended to contain the virus within Wuhan, it served as an impetus for its rapid spread to other provinces and countries as train and bus stations and airports choked with people attempting to flee Wuhan. In the end, about 5 million people - more than the population of many countries - managed to exit. Some even had to cheat by taking antipyretics (Samuel, 2020).

Domestically, Beijing is set to muzzle critics and control public narratives about the outbreak courtesy of President Xi's dexterity of strong, highly centralised, top-down political control. Internationally, Beijing is working hard through top-down diplomacy characterised by relief items, debt cancellations and assertive foreign policy significantly designed to persuade other countries to accept its narrative about the outbreak. Such attempts to influence international public perception are necessary lest it damages its global standing and the image it has built for the Beijing Consensus - at least in the developing countries - and credibility for global leadership. For example, Beijing could influence international organisations like the WHO to refuse the admission of Taiwan to participate in COVID-19 briefings (Economy, 2020). China's aggressive measures to flatten the curve deserves mention. In assessing China's governance capacity to manage the pandemic, COVID-19 has, in turn, become an important test to open the argument between authoritarian governance and democracy. Unlike China, democracies like Italy, Britain, the US, Brazil, among others, have struggled, highlighting some of the weaknesses associated with such regimes. One scholar wrote, "although the COVID-19 epidemic is far from over, China's brand of authoritarian statecraft gains credibility by the day, objections to the state's lack of transparency and accountability notwithstanding" (Peckham, 2020).

One may also argue that the pandemic highlights the regime's weakness and fear instead of strength. The success of President Xi is a function of information censorship and propaganda, strict surveillance of dissenting public and rival leaders, and these may not be signs of strength but fear (Pei, 2020). Thus, it is difficult to maintain that establishing authority through social control, purging dissenting views and fanning nationalism to achieve regime security are signs of strength and confidence. Fear and insecurity accounted for the punishment of the doctors who raised an alarm of impending pandemic and public discussions of it (Zhangrun, 2020). China's response might have been effective, but the argument that hails it cannot be used as a benchmark to judge the effectiveness of authoritarian regimes over democracies. Suppose China's 
success is a function of the Authoritarian political system. How do we explain the successes of democracies like South Korea and, to some extent, Germany in dealing with the virus? South Korea successfully managed the crises with openness, transparency, keeping the people informed, an aggressive testing regime coupled with a heavily wired system (Weber, 2020). Controlling a pandemic largely depends on conscious human interventions that consider the unique domestic characteristics of a particular state. This means that China's success is not a victory for authoritarianism. Similarly, the US or Italy's failure is not a failure for democracy. Instead, countries specific cleverness and capacities in public health.

As the US fans the tales of China's bioweapon agenda and irresponsibility, Beijing recognises the harmful effect the COVID-19 outbreak and the associated theories would have on the successes it has gained for the Beijing Consensus. On this basis, Beijing launched a powerful social media campaign and humanitarian resources to project an image of global leadership to control the international narrative of the virus. It rescued Italy when fellow Europeans ditched it; offered COVID-19 help to Spain; offered COVID19 assistance to Estonia and Lithuania, although both shared a strained relationship with China. Aid was channelled across Europe by Chinese companies and individuals in Beijing's name (Crawford, Martin, \& Bloomberg, 2020). Similar assistance was extended to Africa, including debt reliefs, waivers and extensions of loan maturities (Chen, Li, \& Lin, 2020). Nevertheless, for example, Europe's public perception of China is generally negative, as shown in figures 1,2, and 4. It will be interesting to see how China's COVID-19 aid will charm European leaders or shape positive public perception from the existing negative image on China, exacerbated by the new perception of responsibility of COVID-19 spread. Figure 6 shows that between 2005 and 2018, EU countries received billions of Chinese investments, but this has not translated into a positive attitude towards China but instead increased unfavourable perception. Interestingly, the UK and Germany received the most Chinese investments but did not have a favourable image of China, as figures 1,2 , and 4 reveal. Thus, we cannot find evidence to prove hypothesis two that the expansion of COVID19 aid can help present the Beijing Consensus's attractiveness. However, we can project that the COVID19 outbreak is likely to accelerate the negative perception than the aid able to show the China model's attractiveness.

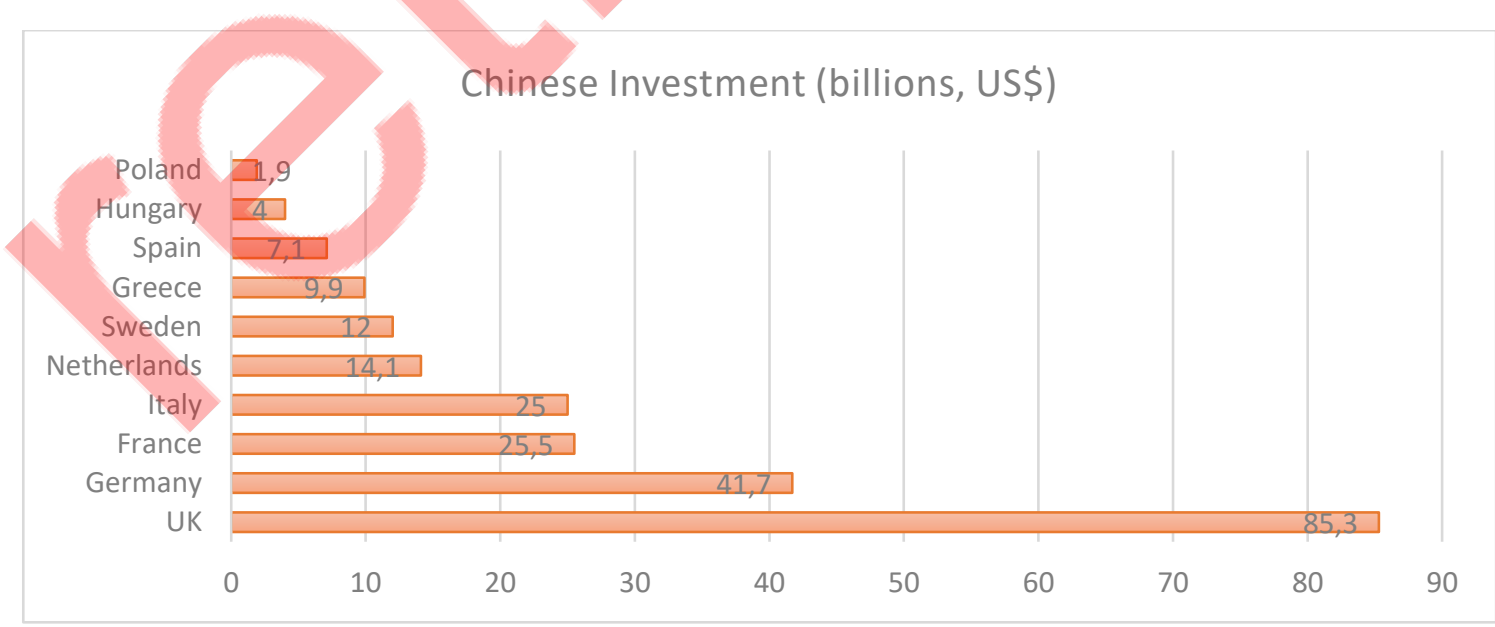

Figure 6. Chinese Investment in Europe by Country, 2005-2018 (billions USD)

Source: Devlin \& Huang (2019), Pew Research Center, March 22, 2019.

https://www.pewresearch.org/fact-tank/2019/03/22/few-europeans-confident-in-xi-as-he-

seeksto-extend-chinese-economic-influence-in-the-region/ (accessed August 4, 2020). 


\subsection{A tainted soft power}

The ways countries have acted on COVID-19 have shaped global opinions about their soft power governance ideals, values and culture. Countries' soft power has either enhanced or worsened. China has been involved everywhere to spread COVID-19 aid but is China's soft power enhanced? A country's soft power is enhanced when its system, political ideals, culture, narratives and innovations are seen as attractive by other countries and willingly emulate to achieve similar outcomes. A country would be able to get what it wants from others "because other countries - admiring its values, emulating its examples, aspiring to levels of prosperity and openness - want to follow it" (Nye Jr., 2004, p.5). Lee Kuan Yew advised that we can know if soft power is achieved only when other nations admire and want to emulate aspects of that country's systems and practices.

China wants to extend its development model abroad - at least to the developing world - and portray itself as a responsible superpower. As figure 5 shows, it was at least gaining points in Africa from the political elites and the public. While some have argued that the Beijing Consensus is Beijing's soft power resource, others point out that it has offered hope as an alternative model to the Washington one for developing countries (Cho \& Jeong, 2008; Ramo, 2004; Zhao, 2010). The COVID-19 outbreak and its theories may undermine this ambition, at least from the perspective of the global public and Beijing's propaganda push to reshape the narrative is evidence of its awareness and concern. Chinese traditional diplomacy emphasises top-down government-government politics and neglects grassroots politics (Gill \& Huang, 2006; Wang \& $\mathrm{Lu}, 2008)$. This is because China understands other countries through the prism of its domestic experience, thus, sees foreign policy as an extension of its domestic politics. Beijing recognises the changes in contemporary international relations and accepts that achieving legitimate international leadership must go beyond government-government to initiate public diplomacy to gain global public approval. One could be convinced that as China beat the COVID-19 crisis, extends its helping hand to others, and even goes further to organise other governments, a triumphant China would be in an excellent position to enhance soft power. It would very much capitalise on its successes to emerge as a world leader or at least be in a perfect place to stake a claim, especially as the US fails at home and abroad.

This is, however, not the case. China's handling of COVID-19 is likely to be measured from the global public views and theories surrounding the pandemic - bioweapon possibility and secrecy that allowed the virus to spread (Huang, 2020; Silver, Devlin \& Huang, 2019; Zhangrun, 2020). Although experts have dismissed the conspiracies, the men-on-the-streets accept them, and they will likely shape and increase a negative foreign publics' attitude towards China. Leaders, especially from the developing world, might have been considering the Chinese model, admiring and emulating it (Zhao, 2010, p. 419). However, the data demonstrate that China before COVID-19 did not enjoy favourable global public views. A comparison of 2018 and 2019 in figure 7 portrays the worsening trend of China's favourability.

Russia held the highest level of favourability. China and Russia have a solid relationship, particularly under President Xi and President Putin. They have established a "bromance" relationship - the rosy and blossoming relationship that extends from state-state to interpersonal level (Smith and Fallon, 2020). China and Russia support each other in international institutions and constantly interact through the Shanghai Cooperation Organization (SCO) and the China-Russia Northeast Asia Security Dialogue since 2015. Although Russia may be worried about Chinese interest in its sphere of interest, mainly as the BRI targets former Soviet and Central Asia states, the interpersonal relation influences Russians perception of China. However, at the onset of COVID-19, Russia became one of the first countries to close its borders to China. In the international system, the ability to affect other countries behaviour to let them want what you want depends largely on a country's values, political ideals and its expression of them. The Chinese values that have allegedly led to COVID-19 spread will likely negatively affect other countries' behaviour and validate 
their prior perceptions as hypothesis one predicts. This negative image the Beijing's system is likely to inculcate in the world public means that the global public will not find the Beijing model attractive to accept or emulate willingly. The figures show that China enjoys favourability from the developing world, especially Africa. However, the perception that sank within ordinary Africans is that the end time has come, and China is the anti-Christ using COVID-19 and 5G internet connectivity to unleash wickedness to end human existence (PASDO, 2020).

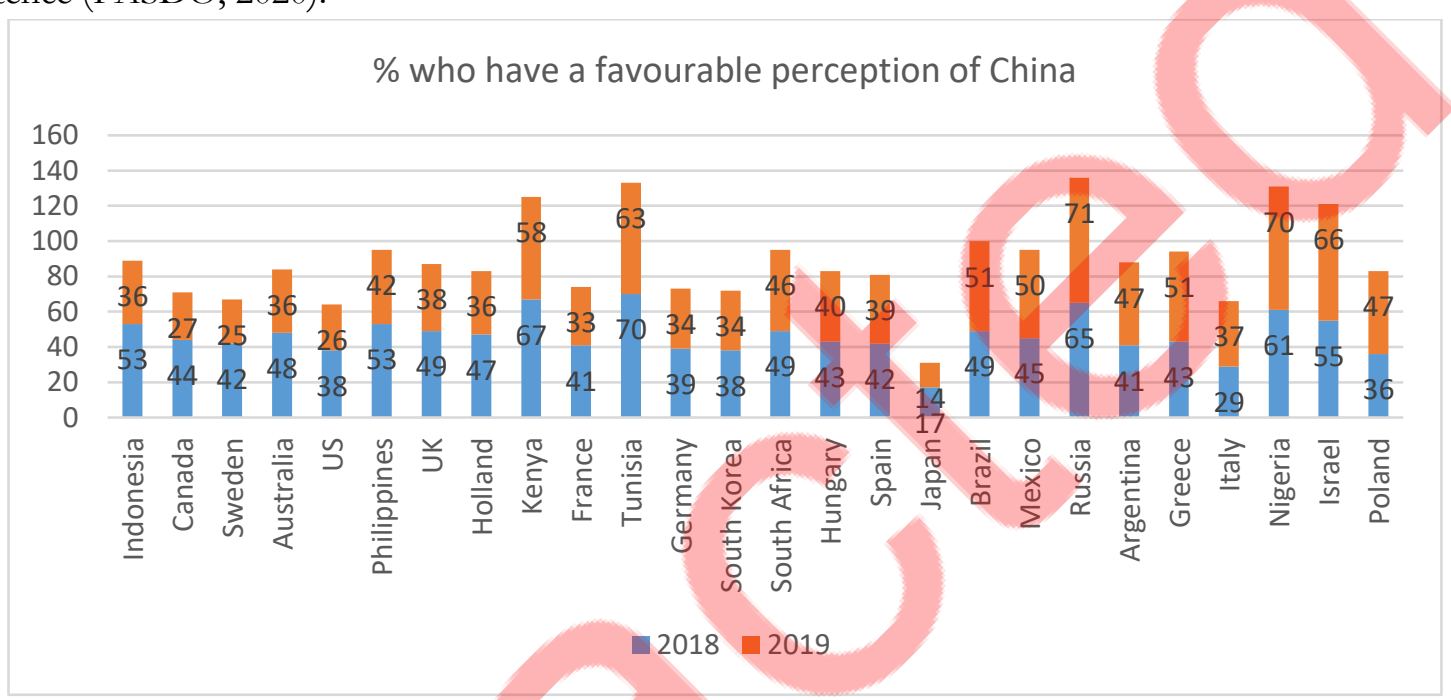

Figure 7. Comparison of 2018 and 2019 China's Favourability

Source: Silver, Devlin \& Huang (2019), Pew Research Center, December 5, 2019.

https:/ /www.pewresearch.org/fact-tank/2019/12/05/people-around-the-globe-are-divided-in-theiropinions-of-china/ (accessed August 4, 2020).

According to Peace Advocacy and Sustainable Development Outreach (PASDO), China is being understood as a racist country in the eyes of many Africans and deepening African hatred for China. PASDO's Africa-China Peace Initiative (CAPI) is thus "aimed at resolving the rising tension between Africa and China related to the handling of Coronavirus" to "help calm the rising hatred for China" (PASDO, 2020). Even in Nigeria with the second-highest China favourability, the July 7, 2020, edition of $A A$ news reported, a group of Nigerians had filed a $\$ 200$ billion against the Chinese government and related institutions over the origin and spread of COVID-19. With an increased global negative image of China, the little attraction that the China model has gained is likely to wane. Kissinger (2014, p.261) wrote that "to achieve a genuine world order, its component, while maintaining their own values, need to acquire a second culture that is global, structural, and juridical - a concept of order that transcends the perspective and ideals of any one region or nation." Thus, China's brand is unlikely to achieve this feat due to the COVID-19 effect.

The argument is that COVID-19 has done damage. China would not be able to convince the global public of its non-liability of the virus spread due to the power of the theories behind it and the medium through which they disperse. From this perspective, China has lost a chance to affirm the attractiveness of its development model to the world's public as an alternative to the Washington Consensus. The COVID19 aids and the social media campaigns aiming to change the narratives on COVID-19 is not likely to be effective. China would have to show much skills of strategic narrative to exercise soft power that would appeal to the sensibilities of the global public and not top-down high politics diplomacy characterised by aids. 


\section{GLOBAL PUBLIC SCRUTINY AND BEIJING'S CREDIBILITY LOST}

Virologists dismiss bioweapons theories. However, it is difficult for Beijing to convince the world's public that it did not delay local and global public's awareness and allowed it to spread globally, especially when the US pushes this information. The notion that China's irresponsibility spread the virus is not only shared outside. Zhangrun (2020) expressed that the virus outbreak "revealed the rotten core of Chinese governance, the fragile and vacuous heart of the jittering edifice of the state [which had] been shown up as never before," pushed citizens who "are all powerless to help each other" into a state of misery, and the disease to the world. Wei Guixian - one of the first COVID-19 patients - also noted that "a lot few people would have died" if the government acted quickly and openly (PTI, 2020b). Before his death, Dr Li noted that "if the officials had disclosed information about the epidemic earlier... it would have been a lot better. There should be more openness and transparency" (Buckley, 2020). A Chinese judge would also rebuke that, had authorities issued early warnings, citizens would have significantly benefitted (Economy, 2020).

Soft power mainly rests on a country's culture, political values, and foreign policies (Nye Jr., 2004, p. 11). These three resources shape all political decisions. Thus, since the blame of the COVID-19 spread is levelled against the Chinese government, it is unlikely that the global public would accept the larger version of this model or values. The pandemic is on the cusp of changing the successes Beijing has achieved in soft power as the global public has inculcated the notion that secrecy, surveillance, and information control spread the global disease, while others still hold on to bioweapon theories. The ability to mobilise "cooperation from others without threats or payments" is a precondition of global leadership (Nye Jr., 2004, p.60). Such precondition must demonstrate competence to provide global public goods, credibility for responsibility and reputation for truthfulness. Through the COVID-19 aid and all other economic payments worldwide, we can say that Beijing could fulfil the former, but the latter becomes the bone of contention. Elizabeth Economy states that "the danger for Xi Jinping is that as the virus spreads globally, the role that China's system of governance played in delaying timely response will face growing scrutiny and criticism from the international community" (Hernandez, 2020).

Figure 3 shows that Americans already blame China for the virus spread as 64\% see China having dealt poorly with the pandemic, and $78 \%$ believe it should be held responsible. This American view could have significant implications by manipulating and influencing the emotions of foreign publics through the control of the international media. Thus, the aggressive postures of Chinese diplomats are standard and defensive because to be silent means acceptance of the narrative, and others will follow, resulting in dire consequences on soft power and credibility. The US's global media influence makes the tale that the Chinese government was behind the virus outbreak gains traction among the international public. The danger of these theories is that they are mostly shared and spread on social media, which reach a larger global audience than research would. They spread faster due to the nature of the target audience and the mere fact that the street by nature takes delight in bad news. The figures show that China, prior to COVID-19, did not enjoy a favourable image. The favourability the US enjoys could influence the global public to validate their previous perceptions of China as hypothesis one suggests.

For example, others like Japan have followed suit following blame, citing China's disinformation and propaganda for the COVID-19 spread. Others have responded to the call for independent inquiry (Euronews \& AFP, 2020). Australia, France, Germany, and the UK have joined the call for an investigation into the origin and spread of COVID-19. Australia "think[s] Australia, the United States and the United Kingdom and countries all around the world would like to know what happened, because we don't want to see it happen again" (Leigh \& Scott, 2020). Blaming China for COVID-19 by the world's powerful countries are likely to influence the global public and validate and even accelerate unfavourable views towards China. It is unlikely that aid could win points to spread Beijing Consensus's attractiveness. For example, their host 
governments summoned Chinese ambassadors to Ghana, Kenya, Nigeria, France, and Kazakhstan on the virus's issues, including accusations of racist maltreatment of Africans due to COVID-19 fears (Erlanger, 2020). While China hopes to deepen bilateral relations to reshape the pandemic's narrative with top-down diplomacy, it is important to highlight that the regime is missing out on the vital area of focus - the global public. The promise of the Beijing Consensus was gaining attraction among leaders and, most importantly, the people, at least in the developing world, as figure 5 and existing literature show (Ramo, 2004; Zhao, 2010). However, the pandemic has caused a dire consequence - the attractiveness embedded in the culture and political values have shaken.

The idea that China is to be blamed for COVID-19 is the reason why a $\$ 20$ million lawsuit was filed against Chinese authorities by some American lawyers and companies who accused China of negligence, aiding and abetting death, conspiracy to cause injury and death, and wrong death (Madhukalya, 2020). However, Carter (2020) explained that "China can't be sued over coronavirus" because "China is protected by the doctrine of sovereign immunity, and the regime's undoubted misconduct does not constitute sufficient grounds for a waiver." A lawsuit and any other charges are unthinkable from China's perspective because it echoes the historic reparations paid after the Boxer Rebellion and the whole history of China's centuries of humiliation (Cohen, 2000, pp.249-63). It has played a major role in cultivating and fanning Chinese nationalist emotions, and every Chinese leader would avoid accepting such terms. Since there are no international legal procedures for such behaviour, the responsibility of condemnation would be left to the opinion of the global public, who would find it difficult to accept Chinese leadership and model due to lost credibility. They are likely to pressure their governments, whose survival depend on periodic elections, to reject Chinese solutions.

\section{CONCLUSION}

The US unwillingness to lead is a structural rather than an individual problem. It means that even after President Trump, the US is unlikely to return to full-scale global leadership readily. Its domestic failures to manage COVID-19 could assume that the liberal order has come to an end. Nevertheless, this does not mean that China stands to gain because it has already lost the trust of the global public and even leaders. A Brazilian Minister argued that China has been profiting from COVID-19: "when the crisis erupted, instead of alerting the world, they withheld information and rushed to build respirators, which they're now selling to a world that's desperate for them" (Brandimarte, 2020). Others are also sceptical that China would have taken over their economies by the time the world finished beating the virus. Global perception data prior to COVID-19 did not favour China, and this negative perception will likely increase with the pandemic. The discussions in this paper show that the COVID-19 pandemic would have dire consequences on China's alternative model because it will validate people's opinions about China and accelerate the already existing situation. The data and the associated analysis thus support hypothesis one that the pandemic outbreak from China is likely to validate the existing negative global public image of China. It further rejects hypothesis two that expanding COVID-19 aid is expected to help redeem its image to present the attractiveness of its model to the world's public.

International relations have become more complicated. Thus, its strategies and conduct corresponding need sophistication. The traditional Chinese diplomacy of high politics makes it to understand others through its domestic experiences. This has caused a misconception about its international image, assuming that national strength directly correlates to an international image. Therefore, a stronger China at home correspondingly draws international respect. This detaches China from the international public. Chinese leadership needs to go beyond its traditional diplomacy characterised by high-politics to initiate public diplomacy to gain global public approval. Without legitimacy by the world's public, China would not be able 
to use its development model as a soft power to establish global leadership. Thus, with American unwillingness, the international leadership vacuum is unfortunately likely to persist for a while because the closest challenger - China - has failed the credibility test and the chance to showcase its model to the world. COVID-19 has proved too costly a distraction.

\section{REFERENCES}

Brandimarte, W. (2020, April 7). Brazilian minister says China has been profiting from pandemic. Bloomberg. Retrieved from https://www.bloomberg.com/news/articles/2020-04-06/brazilian-minister-says-china-has-beenprofiting-from-pandemic?utm_content=business\&cmpid=socialflow-facebook-

business\&utm_campaign $=$ socialflow-organic\&utm_medium $=$ social\&utm_source $=$ facebook_ $($ accessed April $15,2020)$.

Buckley, C. (2020, February 7). Chinese doctor, silenced after warning of outbreak, dies from coronavirus. The New York Times. Retrieved from https://www.nytimes.com/2020/02/06/world/asia/chinese-doctor-LiWenliang-coronavirus.html (accessed March 8, 2020).

Campbell, K. M. \& Doshi, R. (2020, March 18). The coronavirus could reshape global order: China is maneuvering for international leadership as the United States falters. Foreign Affairs. $\quad$ Retrieved from https://www.foreignaffairs.com/articles/china/2020-03- 18/coronavirus-could-reshape-globalorder?fbclid=IwAR020sZxRmkQDY9_LIB7GImRcKrv6GPwKyoSXPOGU2 8Oul0GtLSW_M1u50\&utm_campaign=fbdailysoc\&utmmedium=social\&utmsource=facebook_posts (accessed March 19, 2020).

Carter, S. L. (2020, March 24). No, China can't be sued over coronavirus: nation-states are immune from such lawsuits. Bloomberg. Retrieved from https://www.bloomberg.com/opinion/articles/2020-03-24/can-china-be-suedover-the-coronavirus?utm_medium $=$ social\&utm_source $=$ facebook\&utm_content $=$ busin ess\&cmpid=socialflow-facebook-business\&utm_campaign=socialflow-organic (accessed April 5, 2020).

Chen, S., li, J., Lin, L. (2020, June 18). China to waive some African loan payments due this year, Xi says. Bloomberg News. Retrieved from https://www.bloomberg.com/news/articles/2020-06-17/china-to-waive-some-africanloan-payments-due-this-year-xisays?utm_medium=social\&utm_source $=$ facebook\&utm_content=business\&cmpid=socialflow-facebookbusiness\&utm_campaign=socialflow-organic (accessed June 20, 2020).

Cho, Y. N. \& Jeong, J. H. (2008). China’s soft power: discussions, resources, and prospects. Asian Survey, 48(3), 453-472.

Cohen, W. I. (2000). East Asia at the Center. New York: Columbia University Press.

Crawford, A., Martin, P. \& Bloomberg (2020, March 19). 'Health silk road:' China showers Europe with coronavirus aid as both spar with Trump. Fortune. Retrieved from https://fortune.com/2020/03/19/china-europecoronavirus-aid-trump/_(accessed April 12, 2020).

Devlin, K. \& Huang, C. (2019, March 22). Few Europeans confident in Xi as he seeks to extend Chinese economic influence in the region. Pew Research Center. Retrieved from https://www.pewresearch.org/facttank/2019/03/22/ few-europeans-confident-in-xi-as-he-seeks-to-extend-chinese-economic-influence-in-theregion/ (accessed August 4, 2020).

Durden, T. (2020a, February 1). Coronavirus Contains "HIV Insertions", Stoking Fears over Artificially Created Bioweapon. Zero Hedge. https://www.zerohedge.com/geopolitical/coronavirus-contains-hivinsertions-stoking-fears-over-artificially-created-bioweapon (accessed March 15, 2020).

Durden, T. (2020b, January 26). Did China Steal Coronavirus from Canada and Weaponise it? Zero Hedge. https://archive.is/xI40k\#selection-969.22-969.56 (accessed March 15, 2020).

Economy, E. (2020, February 10). The coronavirus is a stress test for Xi Jinping: can China control an epidemic from the top down?. Foreign Affairs. Retrieved from https://www.foreignaffairs.com/articles/china/2020-0210/coronavirus-stress-test-xi-jinping (February 14, 2020).

Erlanger, S. (2020, May 3). Global backlash builds against China over coronavirus. The New York Times. Retrieved from https://www.nytimes.com/2020/05/03/world/europe/backlash-china-coronavirus.html (May 12, 2020). 
Euronews \& AFP (2020, July 14). Japan accuses China of 'disinformation' over coronavirus outbreak. Euronews. Retrieved from https://www.euronews.com/2020/07/14/japan-accuses-china-of-disinformation-overcoronavirus-outbreak (July 20, 2020).

Feng, E. \& Cheng, A. (2020, February 8). The coronavirus crisis: critics say China has suppressed and censored information in coronavirus outbreak. NPR. Retrieved from https://www.npr.org/sections/goatsandsoda/2020/02/08/803766743/critics-say-china-has-suppressed-andcensored-information-in-coronavirus-outbrea?t=1586503036383 (March 11, 2020).

Gill, B. \& Huang, Y. (2006). Sources and limit of Chinese 'soft power.' Survival, 48(2), 17-36. doi: $10.1080 / 00396330600765377$

Goldsmith, B. E. \& Horiuchi, Y. (2009). Spinning the globe? US public diplomacy and foreign public opinion. The Journal of Politics, 71(3), 863-875.

Goldsmith, B. E. \& Horiuchi, Y. (2012). In search of soft power: does foreign public opinion matter for US foreign policy?. World Politics, 64(3), 555-585.

Haass, R. (2020, April 7). The pandemic will accelerate history rather than reshape it: not every crisis is a turning point. Foreign Affairs. Retrieved from https://www.foreignaffairs.com/articles/united-states/2020-04-07/pandemicwill-accelerate-history-rather-reshape-it (April 10, 2020).

Hernandez, J. C. (2020, March 3). China spins coronavirus crisis, hailing itself as a global leader. The New York Times. Retrieved from https://www.nytimes.com/2020/02/28/world/asia/china-coronavirus-responsepropaganda.html (March 12, 2020).

Huang, Y. (2020, March 5). U.S.-Chinese Distrust is Inviting Dangerous Coronavirus Conspiracy Theories. Foreign Affairs. https://www.foreignaffairs.com/articles/united-states/2020-03-05/us-chinese- distrustinviting-dangerous-coronavirus-conspiracy (accessed March 10, 2020).

Kavalski, E. (2021). The End of China's Romance with Central and Eastern Europe. Global Media and China 6 (1), 77-99. doi: 10.1177/2059436421994442

Kennedy, S. (2010). The myth of the Beijing Consensus. Journal of Contemporary China, 19 (65), 461-477. doi: 10.1080/10670561003666087

Kissinger, H. (2014). World Order. New York: Penguin Press.

Kurlantzick, J. (2013, March 21). Why the 'China Model' isn't going away. The Atlantic. Retrieved from https://www.theatlantic.com/china/archive/2013/03/why-the-china-model-isnt-going-away/274237/ (April $10,2020)$.

Leigh, K \& Scott, J. (2020, May 16). China faces angry world seeking virus answers at key WHO meeting. Bloomberg. Retrieved from https://www.bloomberg.com/news/articles/2020-05-16/china-faces-angryworld-seeking-virus-answers-at-key-who-meeting (May 15, 2020).

Lentzos, F. (2020, May 1). Natural Spillover or Research Lab Leak? Why a Credible Investigation is needed to determine the Origin of the Coronavirus Pandemic. The Bulletin. https://thebulletin.org/2020/05/naturalspillover-or-research-lab-leak-why-a-credible-investigation-in-needed-to-determine-the-origin-of-thecoronavirus-pandemic/_(accessed May 17, 2020).

Li, X. \& Worm, V. (2011). Building China's soft power for a peaceful rise. Journal of Chinese Political Science, 16 (1), 69 89. doi: 10.1007/s11366-010-9130-2

Liang, W. (2012). China's soft power in Africa: Is economic power sufficient?. Asian Perspective 36(4), 667-692. http://www.jstor.org/stable/42704810

Madhukalya, A. (2020, April 2). \$20 trillion lawsuit against China! US group says coronavirus is bioweapon. Business Today. Retrieved from https://www.businesstoday.in/current/world/usd-20-trillion-lawsuit-against-china-usgroup-says-coronavirus-bioweapon/story/399071.html (accessed April 10, 2020).

Martin, S.B. (2002). The Role of Biological Weapons in International Politics: The Real Military Revolution. Journal of Strategic Studies, 25(1), 63-98. doi: 10.1080/714004040

McDonald, J. (2020, February 7). Baseless Conspiracy Theories Claim New Coronavirus was Bioengineered. Fact Check. https://www.factcheck.org/2020/02/baseless-conspiracy-theories-claim-new-coronavirus-wasbioengineered/ (accessed March 3, 2020). 
Naughton, B. (2010). China's distinctive system: Can it be a model for others?. Journal of Contemporary China, 19(65), 437-460. doi: 10.1080/10670561003666079

Nye Jr., J. S. (1990). Soft power. Foreign Policy, 80, 153-171.

Nye Jr., J. S. (2004). Soft power: the means to success in world politics. New York: Public Affairs.

Nye Jr., J. S. (2008). Public diplomacy and soft power. The Annals of the American Academy of Political and Social Science, 616, 94-109.

PASDO (Peace Advocacy and Sustainable Development Outreach) (2020, July 7). Recruit Online Participants and Offer Administrative Support for China-Africa Peace Initiative (CAPI). China-Africa Peace Initiative (CAPI). https://www.pasdo.org/china-africa-peace-initiative/\#vl (accessed July 10, 2020).

Peckham, R. (2020, March 27). Past pandemics exposed china's weaknesses: the current one highlights its strengths. Foreign Affairs. Retrieved from https://www.foreignaffairs.com/articles/china/2020-03-27/past-pandemicsexposed-chinas-

weaknesses?utmmedium $=$ promoemail\&utmsource $=$ prerelease\&utmcampaign $=$ specialsendpeichinacoming_u pheaval_newsletters\&utm_content $=20200403 \& u t m \_t e r m=$ newsletter-prerelease (April 12, 2020).

Pei, M. (2020, April 3). China's coming upheaval: competition, the coronavirus, and the weakness of Xi Jinping. Foreign Affairs. Retrieved from https://www.foreignaffairs.com/articles/united-states/2020-04-03/chinas-comingupheaval (April 12, 2020).

Pradhan, P., Pandey, A. K., Mishra, A., Gupta, P., Tripathi, P. K., Menon, M. B., .. Kundu, B. (2020). Uncanny similarity of unique inserts in the 2019-nCoV spike Protein to HIV-1 gp120 and gag. bioRxiv. Retrieved from https://www.biorxiv.org/content/10.1101/2020.01.30.927871v1.full.pdf_(accessed March 15, 2020).

PTI (2020a, March 19) China's first coronavirus case can be traced back to November 17: report. Business Today. Retrieved from https://www.businesstoday.in/latest/trends/china-first-coronavirus-case-can-be-traced-backto-nov-17-report/story/398174.html (March 20, 2020).

PTI (2020b, March 30) A Wuhan shrimp seller identified as coronavirus 'patient zero'. Economic Times. Retrieved from https://economictimes.indiatimes.com/news/international/world-news/wuhan-shrimp-selleridentified-as-coronavirus-patient-

zero/articleshow/74870327.cms?utm_source=contentofinterest\&utm_medium $=$ text\&utm_campaign $=$ cppst (April 12, 2020).

Qi，B. 齐彬. 2010, (May 12). 习近平勉励东盟留学生学好唐诗宋词成为友好使者 [Xi Jinping encourages ASEAN international students to study Tang and Song Dynasty poems and become friendly messengers]. 中 国新闻网 [China News Network]. Retrieved from http://www.chinanews.com/gn/news/2010/0512/2278741.shtml (accessed January 2, 2013).

Ramo, J. C. (2004). Beijing Consensus. London: Foreign Policy Center.

Reeves, S., Albert, M., Kuper, A. \& Hodges, B.D. (2008). Qualitative Research: Why use theories in qualitative research? BMJ 337 (a949): 630-34. doi:10.1136/bmj.a949

Samuel, H. (2020, January 24). Wuhan woman 'cheated' coronavirus checks to fly out for Michelin-starred meal in France. Telegraph. Retrieved from https://www.telegraph.co.uk/news/2020/01/24/ire-chinese-womancheated-coronavirus-checks-fly-france-michelin/ (accessed March 12, 2020).

Silver, L. \& Devlin, K. (2020, January 10). Around the world, more see the US positively than China, but little confidence in Trump or Xi. Pew Research Center. Retrieved from https://www.pewresearch.org/fact$\operatorname{tank} / 2020 / 01 / 10 /$ around-the-world-more-see-the-u-s-positively-than-china-but-little-confidence-in-trumpor-xi/ (accessed May 4, 2020).

Silver, L. (2017, October 16). How people in Asia-Pacific view China. Pew Research Center. https://www.pewresearch.org/fact-tank/2017/10/16/how-people-in-asia-pacific-view-china/ (accessed August 4, 2020)

Silver, L., Devlin, K., \& Huang, C. (2019, December 5). People around the globe are divided in their opinions of China. Pew Research Center. Retrieved from https://www.pewresearch.org/fact-tank/2019/12/05/people-aroundthe-globe-are-divided-in-their-opinions-of-china/ (accessed August 4, 2020). 
Silver, L., Devlin, K., \& Huang, C. (2020, July 30). Americans fault China for its role in the spread of COVID-19. Pew Research Center. Retrieved from https://www.pewresearch.org/global/2020/07/30/americans-fault-china-

for- its-role-in-the-spread-of-covid-19/ (accessed September 2, 2020).

Smith, N. R. \& Fallon, T. (2020). An Epochal Moment? The COVID-19 Pandemic and China's International Order Building. World Affairs, 183 (3), 235-255. doi:10.1177\%2F0043820020945395

Wang, H. \& Lu, Y-C. (2008). The conception of soft power and its policy implications: A comparative study of China and Taiwan. Journal of Contemporary China, 17 (56), 425-447. doi: 10.1080/10670560802000191

Weber, P. (2020, March 19). COVID-19 hit South Korea and the US on the same day. Here's what Korea did right. The Week. Retrieved from https://news.yahoo.com/covid-19-hit-south-korea-052554080.html_(accessed March 22, 2020).

Xi, J. (2017). The governance of China II. Beijing: Foreign Languages Press Co. Ltd.

Xiaoyang, T. (2020). Co-evolutionary pragmatism: Re-examine 'China Model' and its impact on developing countries. Journal of Contemporary China, 29 (126), 853-870. doi: $\quad$ 10.1080/10670564.2020.1744381.

Zhangrun, X. (2020, February 10). Viral alarm: when fury overcomes fear. (G. R. Barmé, Trans.). China File. Retrieved from https://www.chinafile.com/reporting-opinion/viewpoint/viral-alarm-when-fury-overcomes-fear (accessed March 10, 2020).

Zhao, S. (2010). The China Model: can it replace the Western model of modernization?. Journal of Contemporary China, 19 (65), 419-436. doi: 10.1080/10670561003666061

Zhiming, Y. (2019). Current Status and Future Challenges of High-Level Biosafety Laboratories in China. Journal of Biosafety and Biosecurity, 1(2), 123-27. doi: 10.1016/j.jobb.2019.09.005

Zhou, Y. \& Luk, S. (2016). Establishing Confucius Institutes: A tool for promoting China's soft power?. Journal of Contemporary China, 25(100), 628-642. doi: 10.1080/10670564.2015.1132961 